\title{
Ifa Therapeutic Practices among Yoruba People in Oyo State, Nigeria
}

\section{Bernard E. Owumi Yusuf B. Okewole}

Department of Sociology

University of Ibadan, Ibadan

DOI:10.36108/NJSA/7102/51(0201)

\begin{abstract}
This study examined the Ifa therapeutic system with a view to describing the method, use of herbs and sacrifice employed in treatment process. Although several studies highlighted the importance of traditional healing methods among Yoruba people, none has fully described the systematic process involved in the Ifa practice. Ethnomethodological theory provided the framework. Moniya and Iseyin were purposively selected as study areas. A survey study of 134 respondents was employed through snowballing technique. Twelve In-depth Interviews and two Focus Group Discussions were conducted among Ifa priests in study areas. Quantitative data were analyzed using descriptive statistics while qualitative data were content analyzed. Ifa, being a word of God containing therapy, was performed through divination. Its systematic method relied on procedures and measures domiciled in the 256 corpuses interpreted by Ifa priests. The system is applied to combating illness linked to both physical and spiritual causal agents. The steps involved in the process of providing cure included consultation (68.7\%), making herbal mixtures in combination of many organic and inorganic elements (71.6\%) and use of sacrifice (67.9\%). Ifa therapeutic system is procedural and mainly includes use of herb and sacrifice. In conclusion, Ifa therapy should be formalized to complement western medical care.
\end{abstract}

Keywords: Ifa, therapy, divination, consultation, disease

\section{Introduction}

Ifa in Yoruba mythology refers to the religion or divinity brought into the world by Orunmila. He is the custodian of deity, moral, economy, language, origin and metaphysical orders of the Yoruba nation and of its believers throughout the world (Salami 2002). The basics involve the priest or the mediator called Babalawo with deep knowledge of Ifa who is consulted by clients for solution to life's numerous problems. Healing is an adjunct of Ifa divination. It is added to efficiently negate the power of any "ajogun", the oppressive force (Salami, 2008). The "ajogun" are the demonic forces whose destructive intent is to offset the human body. It is the job of the Oloogun (medicine healer) to help patients overcome the forces. Yoruba medicine has its source in the Ifa corpus- a religious oral information- revealed by the prophet, Orunmila, many years ago in the ancient city of Ile-Ife acclaimed as the source of Yoruba world.

The collective wisdom of the Yoruba people as contained in the Ifa corpus (Odu) includes a huge reservoir of traditional curative and therapeutic 
materials. According to Morakinyo (1983), Odu Ifa is an ancient well preserved oral literature which is the basis of a highly systematized and effective traditional healing system used by Yoruba. The herbs and other materials used in the treatment of diseases are mentioned in the 256 verses (Odu), from Ejiogbe to Ofu see (Jegede 2010). Furthermore, before the introduction of Western medical science, traditional medicine was used in the treatment, diagnosis and management of bio/psycho/social disorders and illnesses. Herbal preparations, rituals and incantations, as reflected in the Ifa corpus (Odu), provided effective therapy. The Babalawos (Ifa priests) often manage these diseases using combination of herbs, rituals and sacrifices. In the Yoruba world view, some supernatural forces such as bewitchment, sorcery, curses, and aggrieved spirits of the ancestors and the breaching of cultural taboos can cause disease (Jegede, 2010).

Healthcare is part of the social system, which can be understood within the context of culture and social structures (Mechanic, 1995). There is, therefore, the need to look at the cultural environment in which the disease manifested, because disease is causing an imbalance, often stemming from a disregard of social, cultural and traditional norms. The Yorubas focus more on the treatment of causes of disease as well as the spiritual dimension of man, than on the symptoms as asserted by Jegede. Ifa divination for healing exists today in spite of the incursion of foreign particular Western culture and medicine into Nigeria. According to Jegede (2005: 276) cited by Ajala, while presenting paper in a conference on "Ifa divination as a diagnostic and therapy device in Yoruba health System", 82\% of clinical cases in orthodox hospitals in SouthWestern Nigeria have consultations with Ifa divination for disease diagnosis and healing. The emphasis and recognition of modern health care is so wide that traditional healing is being degraded for its lack of science with a possibility of going into extinction. Contrarily, subscribers to modern health many times patronize traditional healing after they got disappointed in the failure of modern health care. If traditional healing, through Ifa divination can still be patronized and found efficacious than the supposed sophisticated modern health care, there ought to be a re-assessment and development of the healing system in question. The objective of this study was to examine, through the conception of Ifa, the method of Ifa therapy with special foci on the use of herbs and sacrifices. This work was set out to explore herbal and ritual healing in Ifa corpus, perhaps, it can be adopted to enhance holistic health and healing and as a valuable alternative to orthodox health care. Therefore, it would provide health policy makers with relevant information which can serve as a basis for the integration of modern and traditional medicine in Nigeria. 


\section{Literature Review/Theoretical Framework \\ Ifa Cosmology and Aetiology of Disease}

All forms of good and evil are manifestations of invisible realities-orun. The real causes of things are therefore beyond human's power. The orisa (the -god) and the ancestors (oku orun) are basically good, but if you do not venerate them, certain bad things may happen to you. Inherently, evil powers are attributed to the "ajogun". The ajogun are spiritual entities who are hostile to the well being of others. Odu Ogbe-Rosun describes them as personified and individualized spiritual entities committed to malevolent practices (Jegede, 2010). The orisas are generally friendly to man and are committed to benevolent practices. The belief in the power of these forces causes human beings to worship and venerate them. Worship is therefore a mechanism by which human being cope with the intransigence of the natural environment and the consequences of human activities (Ojo, 1966).

As envisioned by the ancient prophet, Orunmila, of Yoruba, the Ifa Corpus (Cosmic Intelligence) is the text of Osain herbalism. Orunmila saw that dual levels of potentiality existed in the human body. Through him, we understand that the study of animate and inanimate, manifest and latent, visible and invisible worlds leads to fundamental understandings of the processes of growth and life cycles of trees and plants, the lives of insects, animals, and human nature. Through the guidance of Orunmila, the principles of Yoruba Cosmology evolved: "The Self-Existent Being (Oludumare), or the One Source, who is believed to be responsible for creation and maintenance of heaven and earth, of man and woman, and who also brought into being, divinities and spirits (Orisha) who are believed to be his functionaries as intermediaries between mankind and the Self-Existent Being (Oludumare)."

In Ifa, the world is replete with super-natural forces (heaven, ancestors, gods, etc) which appear in various objects such as the sky, mountains, stones, river, trees, forests etc. the Babalawo is the intermediary between the unknown forces and man. He is not only supposed to perform the requested rites through his knowledge of Ifa but also administers healing, (Jegede, 2010). It was through the Ashe (nature) that matter and forces of creation evolved. The earth was created by Olodumare for a divine purpose. The union of Orisha (angelic forces) and Aba (human development) gave birth to the dual potentiality of the human spirit. It is the goal of man to align his earthly consciousness with Ori (the physical and spiritual head) in order to connect with his divinity (www.planetherbs.com).

\section{Use of Herbs for Healing Purposes in Ifa Medical System}

In Nigeria, an estimated $90 \%$ of the rural population and about $40 \%$ of urban dwellers depend partly or wholly on herbal medicine. (Okogwa et al., 2002). Among the Yoruba people in Western Nigeria, Ifa priests often treat illnesses by using a combination of various substances derived from herbal, mineral and 
animal sources. These medicinal herbs are numerous and almost every Odu Ifa contains information on the herbal areas and ritual approaches to disease management. For instance, Odu Ikameji contains highly procedural healing sessions. For example, a patient who sustained an injury from hot water, was treated using this Odu, the healing work was done in different sessions similar to practices in a hospital... several herbal medicines, as well as ointment prepared with shear butter and palm oil were applied on the patient. The results of Ifa divination are usually relevant poems as well as myths. Apart from the prescription of sacrifice, herbal preparations are also given to the client to take at home. The 256 Odu are full of names of herbs, their method of preparation and application for therapeutic purposes. Some Ifa priests claim that all the plants Osayin uses are from Ifa. This implies that an Ifa priest is equally an herbalist... Hence the saying: Bi a ti nkofa, la nko oogun, which literally translates to: as we learn Ifa, we (also pari pasul) learn medicine... Osanyin and Orunmila differ only in their operational methodology, but they serve the same purpose which is the enhancement of holistic healing.

\section{Theoretical Framework}

\section{Ethnomethodology}

Ethnomethodology refers to the study or examination of the methods and procedures used by members of society to construct, account for or give meaning to their social world. Ethnomethodology takes the view that society exists only in so far as members perceive it (or maybe we should say describe it) to exist so that nothing exists except members of society perceive or account for it as such. The accounting procedure in operation here is the "documentary method". This method entails the selection of certain aspects of the infinite number of features contained in any situation and defining them in a particular way and seeing them as evidenced in the underlying pattern. Having done this, "the process is then subsequently used as evidence for the existence of the pattern". The Yoruba people of south western Nigeria are a society or cultural group of people with a unique view of their world. This view or better still their account of the world is explicit in Ifa Corpus.

The Ifa Corpus contains detailed account of the world according to the Yorubas. This explanation of the universe covers every aspect including the health system Mechanic (1995) believes that healthcare is part of the social system, which can be understood within the context of culture and social structures. The account of health system including management of diseases is contained in Ifa's aetiology inherent in the 256 Odus. So the Yorubas' atavistic attachment to Ifa and its practice provide the people with a specific healing system traced to Ifa healing system. This is the reason for most people to continue patronizing Ifa priest for health solution even though in the presence of modern healthcare system. 


\section{Materials and Methods}

The research design for this study was survey. Quantitative data was collected from the beneficiaries of Ifa medical system. Qualitative data were also elicited from Ifa priests who were sampled purposively. The study areas were two different places within Oyo State. These are Iseyin local government area and Moniya in Ibadan. The sample size for the survey method was 134. The questionnaires regarding the number were distributed among the respondents selected through snow ball and accidental sampling. The qualitative method involved the use of structured and unstructured In-depth Interviews (IDIs), Focus Group Discussion (FGD) and participant observation. The survey method involved the use of structured questionnaire which was designed in line with the objectives and administered to one hundred and thirty-four respondents. Information collected on quantitative data was analyzed in line with the objectives using the technique of descriptive statistical tools such as frequency distribution and percentage tables powered by Statistical Package of Social Sciences (SPSS 2014 Version). The qualitative information was translated and analyzed using thematic content analysis in line with each objective of the study.

\section{Data Presentation and Discussion of Findings Socio-demographic Characteristics of Participants (Ifa Priests)}

The report from showed that all the participants in the FGD and IDI were males; this means that Ifa priesthood is mostly practiced by male. This is sequel to some factors affirmed by a babaláwo in Moniya. These factors are patriarchy, restriction of females' role to house chore which invariably affects the time needed to learn the system and also, the fear that such women will not be submissive to their husband. Furthermore, $22.2 \%$ of the participants fell within the age bracket of $21-30,27.8 \%$ fell within the age bracket of $31-40$, and $27.8 \%$ were within the age bracket of $41-50$. This pointed to a fact that most of the priests started learning the system from childhood as apprentices $(22.2 \%)$ till they became adults. Most importantly, all the participants were traditional worshippers. $5.6 \%$ of participants had primary school education, $61.1 \%$ had secondary school education, 22.2\% had NCE/Polytechnic education, $11.1 \%$ had above first degree; thus, none of the participants was illiterate, though the proportion of high qualification which was below the small qualification showed that, there was low level of literacy, perhaps due to inadequate awareness for education traceable to their progenitors. Furthermore, $16.7 \%$ of the participants were full-time babaláwo, $22.2 \%$ were equally students at the time of study, $22.2 \%$ were babaláwo/vocational workers, $11.1 \%$ were babaláwo/Government workers, and $5.6 \%$ were babaláwo/traders, this shows that majority of the participants combine babaláwo work with other jobs. 
On the other hand, the demographic characteristics of Ifa therapy beneficiaries who responded to the survey study revealed that $38.8 \%$ of the respondents were female and 50\% were male. Also, report showed that none of the respondents was below 21 years of age. From the findings, it was evident that $85.8 \%$ of the respondents were Yoruba, $7.5 \%$ were not Yoruba. About $40.3 \%$ of the respondents were Christians, $17.9 \%$ were traditionalists, $41.8 \%$ were Muslims; this shows that there are more Muslims among the respondents than Christians and traditionalists. The result also showed that $3.7 \%$ of the respondents had primary school leaving certificate, 5.2\% have JSCE, 25.4\% had SSCE, 22.4\% had OND, 14.2\% had HND, 10.4\% had NCE, $17.9 \%$ had B. $\mathrm{Sc} / \mathrm{B}$. Ed/BA, and $0.7 \%$ had above first degree; this shows that the respondents are not illiterates. Also, $32.8 \%$ of the respondents were single, $63.4 \%$ were married.

\section{The Conception of Ifa}

The word "Ifa" to an ordinary man walking on the street is nothing but one of the diabolical and obsolete symbols in Yoruba land with little or no relevance to the life of anybody in the present civilization. This is absolutely wrong considering what it is and how it is treated by those associated with it. According to Ifa priests:

Ifa is a guide for human life. If one wants to take a step in life or one needs clarification on something, Ifa is in the position as a guide. Ifa is a religion. (FGD/Babalawo/Iseyin/December/2014)

Another one added as follows;

Ifa is the word of Olodumare (God), the word we use for many different things, powerful words for healing purpose and many other things from which we can derive therapy, story and other wonderful things. All what human being can think of in terms knowledge and wisdom are in Ifa. It is a repository of knowledge and wisdom about the universe. (IDI/Babalawo/Moniyal December, 2014)

From the above, Ifa is generally believed by all babalawos as message from God. It is mainly a guide to humans in all their endeavours among which there is healing system. It is a reservoir of curative and therapeutic materials. The above explanations are in agreement with Ayo Salami thus: "Ifa can simply be said to be the religion or divinity brought into the world by Orunmila... (Salami 2002: xi)." In addition, "igbagbo Yoruba nipe ninu esin lati $n$ wo aisan", meaning that healthcare flows from religion. This is further developed in another way by a babalawo thus:

Ifa being a word from the creator where all wisdoms reside, be it science, technology etc, has numerous usefulness most of which is healing purpose. Everything related to healing is contained in all the odus (verses/corpus) of Ifa. The verses provide information on healing materials, processes or procedures and 
methods of application. Ifa is full of spiritual authority and power (ase) for therapy. (IDI/Babalawo/Moniya/December, 2014)

The above explanation confirms what was quoted under literature review thus: Healing is an adjunct of Ifa divination. It is added to efficiently negate the power of any "ajogun", the oppressive force (Salami, 2008). In a relevant development, the survey study revealed that nearly all respondents confirmed that they $(94.8 \%)$ had benefitted from Ifa medical system. Most Yoruba people resorted to Ifa medical system when the health conditions were perceived as critical (88\%). This result is similar to the findings of Ajala (2007) who stated thus; "It is discovered that about $67 \%(66.8 \%)$ of those who affirmed having consulted Ifa divination when they were sick, did so when they felt they were possibly going to die." He argued furthermore that, "...Certain factors associated with the Yoruba health-seeking behavior work to influence the Yoruba believe in divination as a healing process. The first factor is the perceived threat posed by socio-biological disconformities. When the perceived threat is severe to the extent of seriously threatening the life of the client, consultation with Ifa divination is employed to know the client's state of health." "Among the people, the belief in Ifa divination was so popular that even when patients suffer protracted illnesses in orthodox hospitals, Ifa diviners were consulted to diagnose why the illness had not been responding to treatment. Even when the patients are still in orthodox hospitals, Ifa is still consultation. According to Jegede (2010), $82 \%$ of clinical cases in orthodox hospitals in South-western Nigeria have consulted with Ifa divination for disease diagnosis and healing. This set of patients either directly or indirectly combines the treatments from Ifa healing with treatment received in orthodox hospitals." The above is very true as such happened when Ifa was consulted at the time my friend's mother's health condition was leading to death while she was still in a hospital. This study also showed that, $14.9 \%$ attended Ifa service because they believed in its efficacy, while few (6.7\%) indicated its easy accessibility as a reason. About $6.7 \%$ considered the system affordable. Meanwhile, Odebiyi (1999: 17) suggested that low literacy capacity and poverty as the reasons for preferring traditional health service to modern system. However, 19.4\% respondent chose to do so base on a recommendation possibly from those that had benefitted and realized the efficacy of the system.

Varieties of sicknesses were taken to the custodians of Ifa health system for cure. In order words, nearly all health conditions taken to the modern health care system for treatment were as well attended to by Ifa priests. 


\section{Ifa Therapeutic Procedure}

The first step to take is consultation with Ifa about the patient: consultation starts with putting money (any amount) on opele or eerindinlogun (the sixteen palm nuts), divination would be performed; the priest would then read the result and interpret the odu that appears. The cause of the sickness would be revealed through this. The cause could be loss of property, disease etc. The sickness could even be as a result of biological imbalance in the body, poverty, bad habit or may be, death is looming. If the latter is revealed, Ifa would explain how it would occur, the remedy (if there is any) and other information surrounding the situation. After this, Ifa priest would hear from the patient also to add to the information at hand. This is because "Bi awo ba ki fun ni, aa ki f'awo ni" meaning, as the initiate communicates to one so do one communicates in return. Following this consultation and revelation from Ifa, further consultation would still be done to ask for materials/things to make atonement/sacrifice (if necessary) because the sacrifice is the first thing to tackle the case at hand before any medicine would be prepared. The sacrifice has to do with and to allay invisible forces called ajogun which cause sickness. The forces could attack from the air, water, human body, within the house one lives without awareness, those one that associated with family either from father's side or mother's side. Disease may be contracted from people we relate outside, food and other intakes that are poisonous, and even some things left undone which are suppose not to be. All these can cause sickness. So after tracing and knowing the cause, sacrifice would be done, medical or herbal cure would be applied inform of concoction (agunmu), herb with black soap and others that are necessary. (IDI/Babalawo/Iseyin/Decemder, 2014)

The procedure mentioned above was confirmed by the researcher through a participant observation. Furthermore, most beneficiaries of Ifa therapy indicated that consultation $(68.7 \%)$ was the first action in order to know the nature of a client's condition. The investigator engaged a babaláwo in a divination setting where a disease was diagnosed, followed by herbal medicine preparation to cure it and instruction on the use of the medicine (See appendix). Opele or eerindinlogun depending on the one babalawo is using is an instrument of divination. This is explained further by Ajala (2007) thus "... In traditional divination, Ifa corpus using Opele (Ifa chain), Ikin (sixteen sacred palm nuts), and kola nut are more prominent than other forms of traditional divination. The use of kola nut is also common as divinatory material and it cuts across all the traditional religions in Yoruba society, while the use of cowry, as divinatory item is peculiar among the traditional herbalists who are 
not Ifa devotees, Cowry as a divinatory item does not have wider usage compared to the use of Opele and Ikin, which are associated with Ifa (Ifakorede, 12:7:2004, Int.). Ikin and Opele (see appendix) are more complex than the use of kola nut and cowry. Thus, it requires rigorous and specialized training before one can engage in it. It requires manipulation and strong ability to interpret the signs and symbols through which the message is communicated." The babalawo discovers revelation through the odu (corpus) that appears after divination, the verses of the odu would be recited, interpreted and its instruction would be followed. The odu verse usually contains the cause, description, remedy and procedure to follow to provide good health for patients. Also, any sacrifice as the case may be, would be read as part of the verse. This is corroborated by a participant thus:

Before taking any action, divination performance is the first step and it is from whatever odu (corpus) that appears that we would know what things to do. It may be sacrifice only without adding medication. A person could be bedeviled by spiritual war through wrong utterances or something blew on him/her through the air, it is the odu (corpus) that lead us on the necessary healing steps to perform for the patient. These steps should be adhered to strictly without any addition or subtraction. We ask also from Ifa whether it is necessary to prepare medication and the specific medication to use. (FGD/Babalawo/Moniya/December, 2014)

Another shared similar thought thus;

It is from odu that appears that we would know the things to do or gather for healing. For example, cock, he-goat, hen etc. Some people get healed at ogun (god of iron) shrine, if Ifa says so; Ifa may tell us to prepare cola and water. (FGD/Babalawo/ Iseyin/December, 2014)

A more practical example of Ifa medical practice is presented below. When divination is performed, before which the consultant would have brought out money (any amount) to touch his/her forehead and then put it on the floor where there is eerindinlogun (the sixteen cowries) or opele, depending on the one the babalawo is using to perform divination, whatever odu that appears would be defined and explained by reciting the content of the odu. Each odu (corpus) out of all the 256 existing ones has what it is saying different from others. If it is Eji Ogbe and it reveals death coming; for a female, Ifa can be atoned and after the atonement, it means the death would be averted from her, at all times but she would stop eating all the materials used for the atonement. If it is a child the similar case appears for, i.e. eji 
ogbe, then such child is a stillborn child, as the odu describes thus;

\begin{tabular}{|l|l|}
\hline Yoruba & English Translation \\
\hline Oju abere ni o ni'pin, & $\begin{array}{l}\text { The eye of needle doesn't have } \\
\text { pus }\end{array}$ \\
\hline baluwe ni o gboko, & Bathroom can't contain a car \\
\hline A d'ifa fun Orunmila & $\begin{array}{l}\text { We performed divination for } \\
\text { Orunmila }\end{array}$ \\
\hline baba loree b'emere mule & $\begin{array}{l}\text { Who went to have agreement } \\
\text { with "Emere" }\end{array}$ \\
\hline Ni popo, o ni owo bewe & On a footpath \\
\hline $\begin{array}{l}\text { akoro lo, owo bewe akoro } \\
\text { lo, }\end{array}$ & He should fetch akorolo leaves \\
\hline ati fi oro emere kokin lorun & $\begin{array}{l}\text { We have woven “Emere" } \\
\text { child's matter around Ifa } \\
\text { kernel's neck }\end{array}$ \\
\hline
\end{tabular}

After Ifa has been atoned on behalf of the child, ewe akorolo and akorolo would be used to prepare what he/she would eat. The health of the child would come back to normal. We don't go just to a forest and take any plant; it must be a recommended plant from Ifa corpus that appeared. Perhaps, if it is an adult male, what eji ogbe is saying about him is different as captioned in the corpus.

\section{Use of Herbs in Ifa Therapeutic System}

Herbs take a very important role in providing therapy considering the knowledge of power of plants by Ifa priests. It was gathered from the quantitative data that $71.6 \%$ as against $24.6 \%$ attested that they (respondents) were given herbs for curative purpose. This finding is supported by Jegede (2010) with an assertion that "... in many developed parts of the world, the use of herbs in disease prevention and treatment is very popular." Also, Akerele provided thus; A World Health Organization (WHO) report on herbal medicine estimated that $75-80 \%$ of the world's population rely on herbs for medical purposes. In addition, Jegede noted that, "among Yoruba people in Western Nigeria, Ifa priests (babaláwo) often treat illnesses by using a combination of various substances derived from herbal, mineral and animal sources. These medical herbs are numerous, and almost every Odu contains information on herbal cures and ritual approaches to disease management." This explains different forms in which the herbs are prepared and used on patients by Ifa priests. Majority of the respondents $(36.6 \%)$ were given liquid concoction which was referred to as "agbo" in Yoruba language. Other forms as described by respondents were "agunmu" (ground and dried herbal mixture) $11.2 \%$, according to Jegede (2010), "agunmu" concoction is a special medicament that is processed through burning or drying the ingredients in the sun, pounding, 
grounding and sieving. The aim is to turn the various ingredients into a powder for oral administration. Even though all plants and mineral resources are believed to be useful, not all are edible in their natural state. Some are toxic and can endanger human health..." Concoction combined with soapy herbal mixture $1.5 \%$, black soap mixed with herb3.7\% and balm made from herbal mixture constitute $4.5 \%$ in the result while pounded substances perhaps difficult to describe and other substances made with herbs were $5.2 \%$ and $4.5 \%$ respectively. From findings, respondents described the effectiveness of medication from Ifa healing system. All those that claimed to have benefitted from Ifa healing system declared that they were relieved and healed after medication.

Below is what a participant said during interview:

There are many different ways herb is used. It may be eaten, boiled, and pounded with soap; it may be burnt etc. The healing power of a plant is confirmed in Ifa. This means if we pluck apese leaf, pound it and dilute it with shear butter, it would be applied on the body of the patient after which the rest would taken with hot pap, so the ajogun in the body would be removed. (FGD/Babalawo/Iseyin/December, 2014)

Meanwhile, few participants revealed how these plants came to the knowledge of all babalawos through Orunmila. The following is a story according to a participant;

Orunmila liked to increase his knowledge and therefore he wouldn't look down on anybody. Through his Ifa establishment, his colleagues in Ifa practice performed definition which revealed that he would soon get a slave from whom he would benefit a lot. The slave was Osanyin. Osanyin had knowledge about herbs. One day, Orunmila called on Osanyin and instructed him to weed the backyard of the house. But, rather, Osanyin was telling Orunmila that: "Father, these plants you said I should weed, this is aje leaf (wealth plant), if we use it, it would create wealth, this is aya leaf (plant for getting a wife), and this other leaf can be used for therapy." This is how Orunmila started to improve on his knowledge of herbs. (FGD/Babalawo/Iseyin/December, 2014)

Here is what another participant said while putting light on the connection between Osanyin and Orunmila:

God created Osanyin as an herbalist. But Osanyin established on it through Orunmila, the giant on whose shoulder the Osanyin started to practice with herbs while Orunmila was a specialist in the use of sacrifice for healing. It is their working together that is 
important. Orunmila handed down to his adherents and apprentices, the knowledge on the herbal use of each plant before living the earth. (A babalawo/FGD/December, 2014)

Though everything is inherent in Ifa medical system as stated above. There is an indication that draws difference between an herbalist and an Ifa priest. A babalawo confirmed this thus;

There is little difference between herbalist and Ifa priest on the use of plants and roots. For instance, if somebody complains about not defecating, an herbalist would just think of a plant that can message the body for the person to start defecating. The herbal mixture from the plant may be given to the person to use with hot pap. However, a babalawo when presented with similar case as above, he would firstly make enquiry through consultation being an essential procedure. This is because the case may be caused by some other factors such as, not eating, disease in the body or a normal condition that needs no medication. Sometimes, a medication that works for one person may not work for another person. If a case of headache is presented, an Ifa priest may prepare medicine with rere leaf (Cassia occidentalis) but this may change for another person that presents similar health condition. What determines the action of Ifa priest is the corpus that appears during divination. So, where eje is applied to cure headache, ero(crushed leaves of Kalacheo crenate or Bryophyllum pinnatum mixed with shea butter and oil make an ointment called ero, BepOliver;1986) may be an instructive medicine to use, depending on the cause of the health problem ... Babalawo is like a medical doctor, while we can liken an herbalist to a pharmacist. (IDI/Babalawo/Moniya/ December, 2014)

Further discussion on the use of herbs continues with a participant saying; It is the spiritual power in each plant that works for healing.As we have feminine leaves so also we have masculine leaves. Ewe ina, esisi, oloyin, anragba, osuusu, labelabe etc are examples of masculine leaf and requires one to kill a chick or alternatively, one should pierce himself with blade, all to drop blood before fetching the plants. One may have to drop a coin at the base of a plant tree before plucking its leaf. Each plant has a way of treating each of them before plucking. Ero, odundun (Kalanchoe crenata), tete (Amaranthus Spinosus), rinrin(Peperomia pellucid; Piperacees), woorowo are feminine leaves. (FGD/Babalawo/ Iseyin/December, 2014) 
The reason for categorizing plants into masculine and feminine is due to harmful effect of some plants. For instance, the plants categorized as masculine are difficult to play with. For example, labalabe leaf can cut a person if not handled with care.

... For a sickness that needs herbal cures, there are many plants to use depending on the nature of health condition. For instance, cold and fever; leaves like odundun (Haw life plant/kalanchoe crenata), tete (African Spinach/Amaranthus hybridus), efinrin (Clove Basil/ Occimum gratissimum), woorowo(Senecio biafrae), are the medicinal plants to use. However, for vomiting, koleorogba(Pergulaia daemis; (Aselepiadacees) and ejinrin(Momordica balsmina) can be part of herbal mixture to stop it. For stomach upset, ejinrin and efinrin (Clove Basil) are used. If it is a disease that affects brain, oloora or its root, eso leaf (Bombax buonopozense), ero etc, all these including pig, would be part of medicine to use.Herbs are from plants that grow within our surrounding but each plant has its name. The materials of the leaves and root of a plant can be different, though; this may be the same for some other plants. For example, the materials present in Iyeri(Piper guineense) leaf are also in its root, likewise its seed. However, pepper fruit tastes different from its leaf and root. Therefore, they use them for different purposes. All these observations have been highlighted in Ifa including the description of each plant. (IDI/Babalawo/Moniya/December, 2014)

Another babalawo mentioned some leaves for the cure of stroke thus;

Stroke: Ipeta (Securdaca Longgpeduncalata; Polygalacees) root, eerun (ela), mixed together, lime added, and all boiled for concoction. All these are described by Ifa to be used because things do not just happen without a cause/reason. It can be inflicted by someone, generational etc. Medicines work with faith. Bombom and kafura leaves will be pounded together to form cream. (IDI/Babalawo/Iseyin/December, 2014)

\section{Use of Sacrifice in Ifa Therapy}

It has been stated earlier by a babalawo thus:

...Orunmila was a specialist in the use of sacrifice for healing... (FGD/Babalawo/Iseyin/December, 2014)

Another participant added.

In sacrifice, something like "A di'fa fun" (we performed divination for) usually appears. Most importantly, we use it for 
those things that we want to make happen in future. Ipese aye such as giving out things like fruits to children is part of sacrifice. Deities' shrines such as god of thunder's shrine are part of places where sacrifices are accepted. (FGD/Babalawo/ Iseyin/December, 2014)

In a clearer term, A di'fa fun" (we performed divination for $\mathrm{x}$ ) as indicated above means that such situation has happened to a victim (x) in the distant past -especially while Orunmila was alive- and the story will be recalled in the verse disclosing the nature of the situation at hand and how it was resolved using Ifa therapy system. According to Jegede (2010), "Sacrifice brings about the resolution of the problem presented during divination. At the close of the divination session, after the appropriate verses have been revealed, Ifa is finally asked which deity or spirit should be presented the sacrifice and where it must be placed." An Ifa priest gave an account of one of his achievements where he made use of sacrifice as part of items which healed stroke. Thus:

We have seen an individual who fell sick and could not stand, but when Ifa was consulted, we were told to make a sacrifice that composed of he-goat, pigeon, etc, when this was done, he became hale and hearty. Ifa leaf, odundun (Haw life plant/Kalanchoe crenata) and tete (African Spinach/Amaranthus Hybridus) leaves were used in preparing concoction, Ifa Odi meji corpus was invoked, and the person spat out and excreted every harmful thing in him.

For stroke: Ifa ogbe yonu (corpus) was invoked, there is a verse in the corpus empowered by Olodumare to cure stroke. Thus:

'Okoko ti roko, okoko ti roko, igi seere kan gburugburu, kan seere'

We performed divination for Orunmila, who would do a favor without knowing the course. He was told to make sacrifice of five fowl, to put an end to lack ofwealth and favors. Each of the fowl will be given as a sacrifice to the vulture once in a day. Vulture came from Olodumare (God), it had no hope of survival, it could not stand nor lift its parts of the body; it was seriously sick. Olodumare thought of where vulture could get healing, and wherever such healing comes from, Olodumare promised to do a big favor for the healer. The vulture set out, on getting to the backyard of Orunmila, it saw a sacrifice, and having been feeling hunger, the vulture ate the sacrifice (made of a fowl). Surprisingly the vulture lifted up and was able to raise its right wing. After realizing this surprise healing, he made a journey to the same point on the second day with the hope that there would 
be another sacrifice to eat that will bring further healing. He met it as he thought, and he ate it, the left wing became healed. This continued for complete five days. The vulture became completely healed. He was happy and headed back to Olodumare. Olodumare then decided do a big favour for the healer and therefore ordered the vulture to go and deposit some favours in the custody of the healer. This is why deities rely on Orunmila, whoever wants favour of wealth seeks it from Orunmila. This sacrifice has been used to heal people in various ways. (A babalawo/FGD/Iseyin/December, 2014)

The above suggests that the procedure of healing the vulture as narrated from Ogbe yonu verse was repeated to cure a patient struck by stroke. When asked further about what usually makes up a sacrifice, a babalawo answered thus:

Sacrifice is a combination of release or give out in exchange for something. For a sick person whose condition may lead to death, but asked to sacrifice a goat and does so, the goat has been exchanged for his or her life. If it has to do with witchcraft, we call it ipese. But sacrifice is the general name. For a sickness not caused by witchcraft, it is called etutu, i.e. soothing or relief or easing sacrifice. We know the appropriate place to place sacrifice through Ifa because after divination and sacrifice has been prepared, we would then ask where to put it, insofar as it is stated in the odu corpus that appeared. Using a caption from Eji Ogbe as an example, this goes thus:

\begin{tabular}{|l|l|}
\hline Yoruba & English Translation \\
\hline A d'fa fun Orunmila & We performed divination for Orunmila \\
\hline To lo ree ba emere mule & Who had a covenant with "Emere" \\
\hline Ni popo & On a footpath. \\
\hline
\end{tabular}

From there, we know such sacrifice has to be put on a footpath or road. Some are meant to be placed on road junction, others, at a river side or at the front of the house. What is happening to a patient sometimes determines where to place a sacrifice. For somebody that can't sleep, sacrifice may be put at his/her window side or at the front of the house. For a sick somebody that has travelled or far away from where we are, it is possible to place sacrifice (etutu) on the road or at a road junction. (IDI/Babalawo/Moniya/December, 2014)

However, what are the properties of sacrifice was a question that elicited the response below from a participant. 
Anything can be part of a sacrifice except what is not asked by Ifa. Sacrifice is a food for invisible supernatural forces. Everybody has spirit with which we communicate with. Whoever sees a sacrifice and eat from it, such person would have been led by the spirit living inside the person. Then, the sacrifice would be accepted for the person that brought it.

He continued thus;

Inherent in the above is that some animals and even humans that eat sacrifice put at strategic places would have been possessed by supernatural force for which the sacrifice is meant for. This debunks a belief of some people that sacrifice by Ifa priest is a waste and has no effect. The supernatural forces that will heal a person are invisible. Wherever a person's healing lies is where the sacrifice will be deposited, not just junctions. Spirit of supernatural beings such as iwin, alujonu, egbere, ebora (demons) and ghost, those walk with the air. A person can fall victim of sicknesses from them. If Ifa says those who will accept the sacrifice are at a junction, the sacrifice goes to the junction. Other places are river bank, roadside, bathroom, forest, plantain plantation, yam farm, backyard; at the appropriate time such as morning, afternoon or evening, depending on the instruction. Wherever the person is going to be delivered by the oniko (invisible force) is where Ifa indicates for the sacrifice to be put. These oniko(s) can possess a goat, dog, ant, lamb to eat the sacrifice. (IDI/ Babalawo/Moniya/December, 2014)

Therefore, every action taken towards healing purpose is a directive to Ifa priests acquired from the verses of Odu Ifa as handed down by Orunmila. Meanwhile, results from survey supporting the above from clients of Ifa therapy system revealed that $67.9 \%$ which is the majority of the respondents confirmed that there was application of sacrifice on their health issue as against $27.6 \%$. The importance of sacrifice was well established by FGD participants and IDI respondents in this work. Thus, according to a participant, as stated earlier on, "... Orunmila was a specialist in the use of sacrifice for healing... we use it for those things that we want to make happen in future. Ipese aye such as giving out things like fruits to children is part of sacrifice, (FGD/Babalawo/Iseyin/December, 2014). In the work of Jegede (2010), "Illnesses... are handled with a combination of herbal medicine and rituals, since the disease are believed to be from both natural and spiritual causes."

Anything can make up a sacrifice as stated earlier. William Bascom (1969) agreed with the above noting that; it is not surprising therefore, to find a babaláwo using a number of extremely varied objects for sacrifice. An analysis of 60 verses from the Odu Ifa reveals that money and livestock are required for 42 sacrifices, 12 of which require different types of livestock, 
bark, leaves, roots, and many other mineral and animal substances. Jegede (2010) goes further to note that domestic animals (fowl, dogs, pigeons), various non domestic animals, dried rats, fish, snails, eggs, yam, maize, palm oil, beans, kola nuts, axes, bits or iron, chalk, whips, cutlasses, razor blades, rings, beads, drums, or any other item deem appropriate could be one of the items for sacrifice." $23.1 \%$ of the respondents claimed that the reason behind the use of it was to ward off evil spirit. The evils spirits include supernatural and invisible forces that can cause sickness. However, other reasons such as 'to restore good health $6 \%$, to seek good health from God $6.7 \%$ and to appease god 6\%" all correspond to what a babaláwo said thus; "...Wherever the person is going to be delivered by the Oniko (invisible supernatural force) is where Ifa indicates for the sacrifice to be put. This explains why in Ifa, therapeutic system, the use of herbal preparations alone cannot achieve holistic healing, but must be accompanied with etutu. From the word "tutu" meaning cool, connoting peace and harmony.

Majority of the respondents preferred Ifa medical system because they perceived that the therapy is effective. Similarly, respondents $3.7 \%$ preferred it because it cured their health problem permanently. This is an issue with modern health care because some people, after living orthodox hospital head to Ifa priests after complaining about the enduring symptoms of illness taken to the hospital. This is in line with the reason why people resort to babaláwo after the orthodox hospital failed. Meanwhile, 5.2\% respondents claimed that it was because of its affordability and $1.5 \%$ indicated its easy accessibility as an encouraging factor. This is supported by Chiwuzie et al., noting "that the majority of people of Nigeria use traditional rather than western medicine for reasons of culture, cost and availability."

\section{Conclusion}

This study was conducted on the Ifa therapeutic system - procedure involved in Ifa medical system, the use of herbs and sacrifice. Ifa is a word or message from Olodumare (God), which can be found in the 256 literary corpuses, as revealed through divination by a versed Ifa priest. This can be found in "Ifa, a complete Divination". It contains a systematic and holistic procedure of healing which had existed prior to the emergence of western medical care (Jegede 2010). It is an integration of religio-therapeutic experience centered on providing healing to the knowable and the treatable without isolating the mind and the immediate environment. The divination process which centers on diagnosis can also offer a rational explanation of sickness, though it covers the transcendences of physical sickness of the body other than how a patient views or feels. In other words, the Ifa medical system with its belief about etiology of disease goes beyond biological, emotional or psychological aspects but also includes the spiritual and supernatural forces, hence, its description as being holistic. 
While this therapy system is found to be widely patronized within the Yoruba people of south western Nigeria, some views considering the system as diabolic need to be discarded. The attitude of government towards promoting the indigenous Ifa medical system is much more needed. The government should establish a regulatory agency that would work towards the objective of systematic process of formalizing the Ifa healing system such that it would be integrated with western medical system. It should be upgraded to enjoy the same recognition with its western medical system counterpart. Practitioners of Ifa therapy should be keen to spread their knowledge, expertise and healing experience to bear at the national level to ensure the survival and promotion of the system so that modern indigenous African medical system would emerge. Furthermore, the method of packaging medicine should be developed in a modernized way, just like other nations whose methods of drug packaging is sophisticated. In addition, the medical practitioners in the orthodox hospitals should create an open and accommodating mind for traditional healing system, through objective appraisal of the system and allow mutual relationship in surmounting the challenges of diseases and sicknesses.

\section{References}

Adesogan, E.K. (1999). Scientific rationale for selected Nigerian traditional remedies. In Standardizatiion and Utilization of Herbal Medicine Challenges of the $21^{\text {st }}$ Century. In J.O. Moody, and E.O. Ajaiyeoba et al. (Eds.). Proceedings of an International Workshop Department of Pharmacognosy, University of Ibadan.

Ajala, A.S. (2007) Ifa Divination as a Diagnostic and therapeutic Device in Yoruba Healing System. International Conference on "Global African Spirituality, Social Capital and Self-Reliance in Africa". Department of Archaeology and Anthropology, University of Ibadan, Ibadan.

Akerele, O. (1993) Guidelines for the Assessment of Herbal Medicine (WHO, Geneva, 1991). Herbalgram, 28: 3-20.

Akin-Otiko, Paul (2012) Diagnosis and Treatment of Amodi in Ifa Divination among the Yoruba of South Western Nigeria. Being a post-field presentation to the Institute of African Studies, in partial fulfillment of the requirement for award of Doctor of Philosophy in African Studies, University of Ibadan.

Ayo Salami (2002) Ifa: A Complete Divination. NIDD. Lagos.

Bascom, William (1969) Ifa Divination; Communication between Gods and Men in West Africa. Bloomington: Indian University Press.

Buckley, Anthony (1985) Yoruba Medicine. New York: Clarendon Press.

Chiwuzie J. et al. (1987) Traditional Medicine; Traditional practitioners are here to stay. World Health Forum Vol. 8.

Eddiefloyd, M. (2003). Basic Sociology. Enugu: CIDJAT Publishing and Press. Edward, Garry and John Mason (1985) Black Gods: Orisa Studies in the New World. Ptiman, Yoruba Theology Archministry, New York. 
Fakayode Fayemi (2011) Iwure, Efficacious Prayer to Olodumare, The Supreme Force. Ejodi Home of Tradition, Ibadan.

Farma, Aina (2009) Reflections on the Wisdom of Ifa. Ile Orunmila Communications, San Bernardina, C.A.

Forster, G.M. and John Q. Anderson (1978) Disease etiology in non- Western medical Systems. Journal of American Anthropology. Vol. 78.

Haralambos and Holborn. 2008. Sociology, Themes and perspectives. London: Harper Collins.

Jegede, O. (2010) Incantations and Herbal Cures in Ifa Divination: emerging issues in indigenous knowledge. African Association for the study of Religion, Ibadan: Nigerian Publication Bureau.

Mbiti, J.S. (1966) The Yoruba Culture. Ibadan: Oxford University Press.

Mechanic, C.D. (1995) Emerging trends in the application of the social sciences and Medicine. 40, (2).

Morakinyo, O. (1983) The Yoruba Ayanmo myth and mental health care in West Africa. Journal of culture and Ideas. 1(1): 87.

Ojo, G.A. (1966) The Yoruba Culture. Ibadan: Oxford University Press.

Okogun, J.I., H.C. Ufford, A.L. Inyan and D.T. Okpako (2002) A paper presented at the International seminal/Workshop on Complementary Traditional Medicine. University of Ibadan.

Olatunji, O.O. (1984) Features of Yoruba Oral Poetry. Ibadan: Ibadan University Press.

Oliver-Bever, B.E.P. (1986) Medical Plants in Tropical West Africa. Cambridge: Cambridge University Press.

Olutayo, A.O., Akanle, Olayinka (2003) Sociological Theory for African Students. Ibadan: Ibadan University Press.

Raaji, S.M. (1991) Ijinle Ofo, Ogede ati Aasan. Ibadan: Onibonoje Press.

Sofowora, A. (1982) Medical Plants and Traditional Medicine in Africa. Ibadan: Spectrum Books.

Verger, Pierre Fatunbi (1995) Ewe: The use of plants in Yoruba society. Brazil: Odecrecht Press.

Tariq Sawandi (2000) The Art of Divine Herbology. www.assatashakur.org /forum/African-wholistic-health/24889-yoruba-medicine-artdivineherlbolo gytariqsawandi. 


\section{APPENDIX}

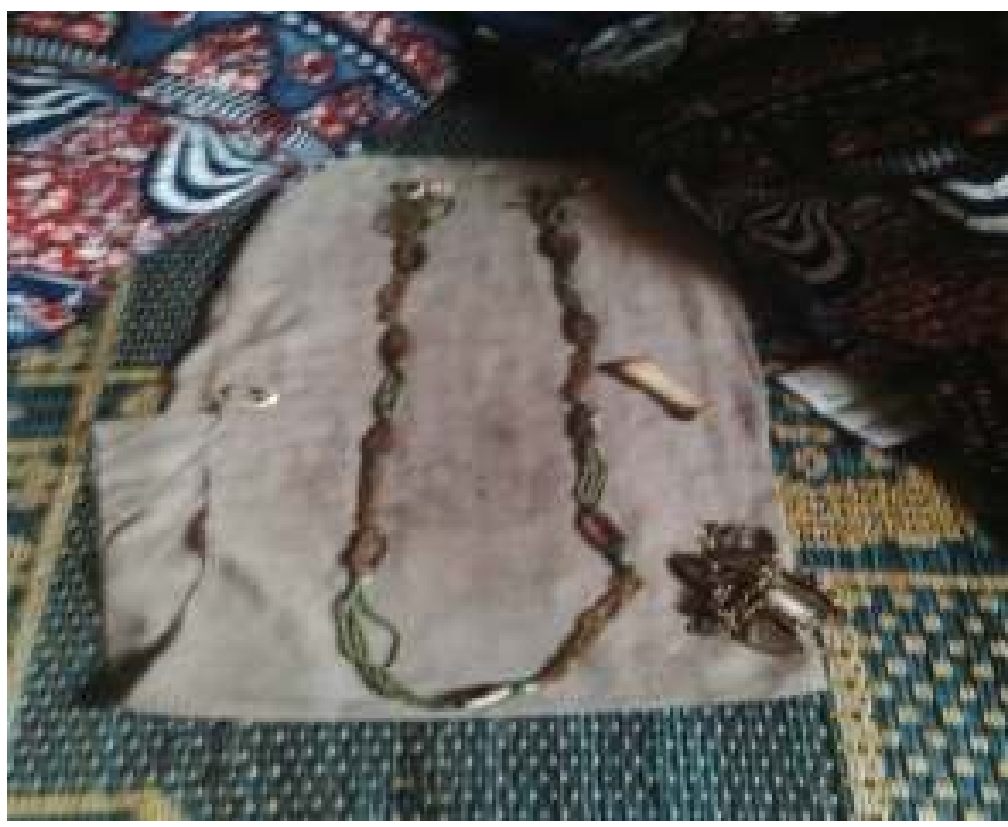

These are divination instruments: the U-shaped long lines of beads decorated and tightened at interval is called Opele, at the left hand side is a cowry and a bone at the right hand side both which are called "ibo",(voting instruments). They are all on small piece of white cloth spread on a mat. There is fifty naira note beside the white cloth, the money that is put down for consultation by a client. Another object at the right corner bottom is another Opele but made of brass. (IDI/IFA PRIEST/MONIYA/DECEMBER, 2014) 